DOI https://doi.org/10.30525/978-9934-588-80-8-2.25

\title{
АНАЛІЗ ПСИХОЛОГІЧНИХ ТА СОЦІОЛОГІЧНИХ ТЕОРІЙ ОСОБИСТОСТІ ЯК КОНЦЕПТУАЛЬНИХ ЗАСАД НЕФОРМАЛЬНОЇ ОСВІТИ
}

\author{
Самохвалова І. Ю. \\ аспірант \\ Сумський державний педагогічний університет імені А. С. Макаренка \\ Харченко С. М. \\ кандидат педагогічних наук, \\ доиент кафедри фізичного виховання \\ Сумський національний аграрний університет \\ м. Суми, Украӥна
}

Прагнення особистості до саморозвитку, самовдосконалення та професійного зростання - основні риси представників інформаційного суспільства. Ці запити може задовольнити неформальна освіта, головне завдання якої підготувати здобувача освіти до самостійного життя, не формувати в ньому пасивного «споживача» знань, а виховувати активну, цілеспрямовану та зацікавлену у пізнанні багатогранну особистість.

Впровадження неформальної освіти в освітній простір закладів вищої освіти вимагає консолідації усіх сторін, зацікавлених в підвищенні якості освітніх послуг: закладів вищої освіти, працедавців, студентів [3, с. 333].

Неформальна освіта грунтується на ряді принципів, найбільш важливі 3 яких - вчитися в дії (отримувати різні вміння та навички під час практичної діяльності), вчитися взаємодіяти (розуміння про відмінності, які існують між людьми, вміння працювати в групі і в команді), вчитися вчитися (отримувати навички пошуку інформації та ії обробки, навички аналізу власного досвіду і виявлення індивідуальних освітніх цілей [2].

Різноманіття видів неформальної освіти та наявність запиту суспільства на її здобуття потребує системного вивчення і дослідження даної проблеми.

Один із видів неформальної освіти - це неформальна фізкультурна освіта.

Неформальна фізкультурна освіта - доцільно організований, цілеспрямований процес навчання, виховання й розвитку молоді, який 
враховує іiі потреби у повсякденному виконанні фізичних вправ, самовихованні психологічних якостей борця за своє здоров'я, як необхідної умови досягнення високих соціальних стандартів та реалізації професійних надбань та не завершується наданням кваліфікації того чи іншого рівня [5].

Мета дослідження: аналіз психологічних та соціологічних теорій особистості на які спирається концепція неформальної освіти та визначення реалізації цих ідей в неформальній фізкультурній освіті.

При окресленні концепцій неформальної освіти дослідники визначають різні вихідні теорії. Виходячи 3 мети неформального навчання, важливим для розвитку теорії $є$ погляди Дж. Дьюї, ідеї А. Маслоу та К. Роджерса, педагогіка П. Фрейре.

Згідно $з$ педагогічними ідеями Дж. Дьюї в основі навчально виховного процесу повинні лежати інтереси того, хто навчається. Якість та кількість навчання має визначатись не програмою а учнем. Дж. Дьюї був впевнений, що «освіта стане більш повною і глибокою, а навчання тривалішим й інтенсивнішим, якщо воно виростатиме із запитів, інтересів і потреб учня» [4].

В сфері неформальної фізкультурної освіти ця ідея реалізується в суб'єкт - суб'єктному навчанні, яке формує суб'єктність як особистісну рису студентів та викладачів і може бути реалізовано лише за умови вибірковості змісту занять 3 фізичного виховання. Це підвищить навчальну мотивацію студентів та їх відповідальність за результати навчання, також суттєво підвищить якість викладання.

За теорією Дж. Дьюї навчання пов'язане з виконанням дії. Через навчання в дії в учня може з'явитись бажання до подальшої самоосвіти. Через таке навчання формуються певні властивості характеру, що дають змогу контролювати, що відбувається навколо і пристосовувати до своїх цілей $[2,4]$.

У неформальній фізкультурній освіті ця ідея може бути реалізована таким шляхом: акцентувати увагу на професійно - орієнтовані теми, форми, методи навчання, надавати перевагу активним та інтерактивним методам, що стимулюють формування якостей (вміння працювати в команді, відкритість, критичність, вміння навчати тощо).

Розглядаючи участь людини у неформальній освіті як процес іiі самоактуалізації не можна не згадати гуманістичну теорію навчання в основі якої лежать ідеї А. Маслоу та К. Роджерса.

За теорією А. Маслоу подолання меж своїх можливостей $\epsilon$ важливою та природженою рисою людської природи, тому що людина долає межі, аби стати собою, щоб краще самореалізуватися в житті. 
Початковою метою людини є іiї розвиток, а рушійною силою - потреба само актуалізації [1].

Навчання має допомогти людині зрозуміти моменти в яких мотивація та цінності, котрі вона хоче реалізувати, стають більш зрозумілими. Ця позиція А. Маслоу доповнюється поглядами К. Роджерса.

К. Роджерс розділяє учіння на: примусове (спрямоване на засвоєння знань) та вільне і самостійне (спрямоване на засвоєння смислів, як елементів особистого досвіду, а тому осмислене). Самостійне учіння сприяє розвитку здатності робити самостійний вибір [2, с. 32].

Згідно з позиціями А. Маслоу та К Роджерса, гуманістично орієнтована освіта має наступні характеристики:

- бере витоки 3 загальнолюдських цінностей, що базуються на цінностях різних культур;

- iї метою є самореалізація особистості;

- відбувається в єдності розуму та почуттів, у цілому сприяючи холістичному (цілісному) розвитку особистості;

- людина вільна в своєму виборі змісту, форми і режиму освіти;

- державні та громадські органи є фісилітаторами (тими, що допомагають, полегшують), а не формальними керівниками [7].

Із вище зазначеного, можна визначити принципи неформальної фізкультурної освіти, побудованої на засадах гуманістичної педагогіки: орієнтованість на потреби тих хто навчається, значущість досвіду, розвиток емоційної сфери, підвищення самооцінки, створення можливостей для самореалізації [2, с. 36].

Помітний вплив критичної педагогіки П. Фрейре на розвиток неформальної освіти.

Як стверджував П. Фрейре, використання діалогу в процесі навчання $\epsilon$ необхідною складовою для одержання найкращого результату засвоєння знань. Бразильський педагог виділяв створення діалогічної атмосфери, що дасть змогу нормально працювати педагогами та учням (студентам) у сучасному демократичному суспільстві [6].

Здійснюючи екскурси в дослідження теорії і практики, П. Фрейре вважав, що практиці необхідна теорія, а теорії потрібна практика. Теорія, втілена на практиці, допомагає людині розуміти практику, відображаючи та вдосконалюючи їі $[2,6]$.

У неформальній фізкультурній освіті ідеї П. Фрейре реалізуються через зв'язок навчання з життям, самокерованість, суб'єкт - суб'єктну взаємодію учасників навчального процесу.

Таким чином, теорія неформальної освіти та неформальної фізкультурної освіти базується на філософських, соціальних та психо- 
логічних ученнях, які протиставляють за змістом формальний (масовий) та неформальний (індивідуалізований) змісти освіти.

\section{Література:}

1. Маслоу А. Новые рубежи человеческой природы. М.: «Смысл», 1999. $424 \mathrm{c}$.

2. Павлик Н. Теорія і практика організації неформальної освіти молоді: навчальний посібник. Житомир: Вид-во ЖДУ імені I. Франка, 2017. 162c.

3. Рибалко П. Ф., Самохвалова І. Ю. Аналіз розвитку рухових здібностей студенток закладів вищої освіти засобами спортивних ігор у процесі секційних занять. Modern researcher in psychology and pedagogy: Collectivemonograph.Riga: Izdevnieciba «Baltija Publishing», 2020. 428 p. C. $333-352$.

4. Рогозіна Л. А., Нагур А. А., Залюбівська О. Б. Педагогічні ідеї Дж. Дьюї у світлі сучасних освітніх тенденцій. URL: conferences. vntu.edu.ua > all-hum > paper > download (дата звернення 8.09 20202).

5. Самохвалова І.Ю. Неформальна фізкультурна освіта студентів. Вісник Національного університету «Чернигівський колегіум» ім. Т. Г. Шевченка. Серія: Педагогічні науки. Випуск № 3 (159). Чернігів, 2019. C. 292-295.

6. Турчин I. М. Освітня діяльність та педагогічні погляди Пауло Фрейре: дис. ... канд. пед наук : 13.00.01. Львів, 2015. 308 с.

7. Федоренко С. В. Гуманістично-культурологічна парадигма як методологічна основа формування гуманітарної культури студентів вищих навчальних закладів США. Педагогічні науки:теорія, історія, інновачійні технологіï, 2014. № 4 (38). C 66-75. URL: http://nbuv.gov.ua/ UJRN/pednauk_2014_4_9 